\title{
Food web interactions in the southwestern Barents Sea: black-legged kittiwakes Rissa tridactyla respond negatively to an increase in herring Clupea harengus
}

\author{
Robert T. Barrett* \\ Zoology Department, Tromsø University Museum, 9037 Tromsø, Norway
}

\begin{abstract}
Since 1980 the stock of Norwegian spring-spawning herring Clupea harengus has increased 10 -fold to $>5 \times 10^{6} \mathrm{t}$. This increase has probably played a vital role in repeated collapses in the capelin Mallotus villosus stock in the Barents Sea since the mid-1980s. After several decades of increase during a period of high capelin abundance in the Barents Sea, the population of blacklegged kittiwakes Rissa tridactyla breeding in northern Norway started to decline in the early 1980s, reaching rates of $-8 \% \mathrm{yr}^{-1}$ since 1995. Earlier studies in the southwestern Barents Sea suggested that the black-legged kittiwakes in the region were dependent on capelin as prey for successful breeding. This study further documents a positive relationship between diet composition and fish abundance, and the negative effect that a switch to feeding on herring in the absence of capelin has had on chick provisioning and possibly fledging success.
\end{abstract}

KEY WORDS: Seabirds $\cdot$ Black-legged kittiwake $\cdot$ Diet $\cdot$ Breeding success $\cdot$ Food web interactions Resale or republication not permitted without written consent of the publisher

\section{INTRODUCTION}

The black-legged kittiwake Rissa tridactyla, a small gull with a northern circumpolar distribution, is a very common breeding species in the arctic and boreal zones. They feed, often in flocks, at the ocean surface mainly on invertebrates and, especially during the breeding season, on small fish (up to 15-20 cm).

In Norway, the mainland population was estimated at 336000 pairs in 2005, with $>90 \%$ breeding north of the Arctic Circle (Barrett et al. in press). Between 1960 and 1980, the Norwegian population increased at a rate of ca. $1 \% \mathrm{yr}^{-1}$, but since 1980 it has declined rapidly, by as much as 50 to $75 \%$ (between 1980 and 2005) on 4 annually monitored sites, and since the mid1990s at rates of 6 and $8 \% \mathrm{yr}^{-1}$ in less frequently visited colonies in the Norwegian Sea and Barents Sea, respectively (Barrett et al. in press). As a result the black-legged kittiwake is now categorized as vulnerable on the Norwegian Red List.
In earlier studies at Hornøya $\left(70^{\circ} 23^{\prime} \mathrm{N}, 31^{\circ} 09^{\prime} \mathrm{E}\right)$ in the southwestern Barents Sea, Furness \& Barrett (1985) suggested that of the several seabird species breeding in the colony, the black-legged kittiwake was among those most dependent on capelin Mallotus villosus as a food source. This was later corroborated by evidence of a positive association between the breeding success and population trends of black-legged kittiwakes and the regional stocks of capelin (Krasnov \& Barrett 1995). Furthermore, the increase in black-legged kittiwakes in the region between 1960 and 1980 was suggested to be a response to an abundance of capelin in the Barents Sea at a time when the stock of Norwegian springspawning herring Clupea harengus was at a minimum (Barrett \& Krasnov 1996). Capelin stocks were first assessed in 1973, and in the following $10 \mathrm{yr}$ ranged between 4 and $10 \times 10^{6} \mathrm{t}$ (Iversen et al. 2006). After the late 1980s, however, the herring spawning stocks started to recover and increased from $<500000$ to $>5 \times$ $10^{6} \mathrm{t}$ in 1995 (ICES 2006a). Increasing numbers of 
young herring in the Barents Sea have, through their predation on capelin larvae, a negative effect on capelin recruitment and have probably played a vital role in the stock collapses of capelin during 1985 to 1989 and 1993 to 1998 (Fig. 1; Hjermann et al. 2004). In this context, Barrett \& Krasnov (1996) predicted that the black-legged kittiwake population would experience decreased breeding success associated with reduced levels of capelin in the diet. Since this forecast, the herring stock has remained high (5 to $8.5 \times$ $10^{6} \mathrm{t}$ ) with periodic high recruitment levels, while the capelin built up to a low peak in 2000 only to collapse again in 2003 to 2005 (Fig. 1; Iversen et al. 2006). Concurrently, the population of black-legged kittiwakes on Hornøya has declined at a rate of $2 \% \mathrm{yr}^{-1}$, from 19000 pairs in 1983 to $11500-12000$ pairs in 2006 (Krasnov et al. 2007). This study explores the diet and breeding success of black-legged kittiwakes on Hornøya during this period of greatly varying capelin and juvenile herring stocks and Barrett \& Krasnov's (1996) prediction of a reduction in breeding success as a result of low capelin abundance.

\section{MATERIALS AND METHODS}

Diet analysis. Since 1980, black-legged kittiwakes on Hornøya have been the subject of a variety of studies that have involved the capture of both adults and offspring during the chick-rearing period. Because both age groups often spontaneously regurgitate the contents of their proventriculus when handled, food was sampled by collecting these regurgitations whenever the opportunity arose. Each regurgitation was collected in a plastic bag, labelled and stored in a deep freezer. Because few samples were collected between

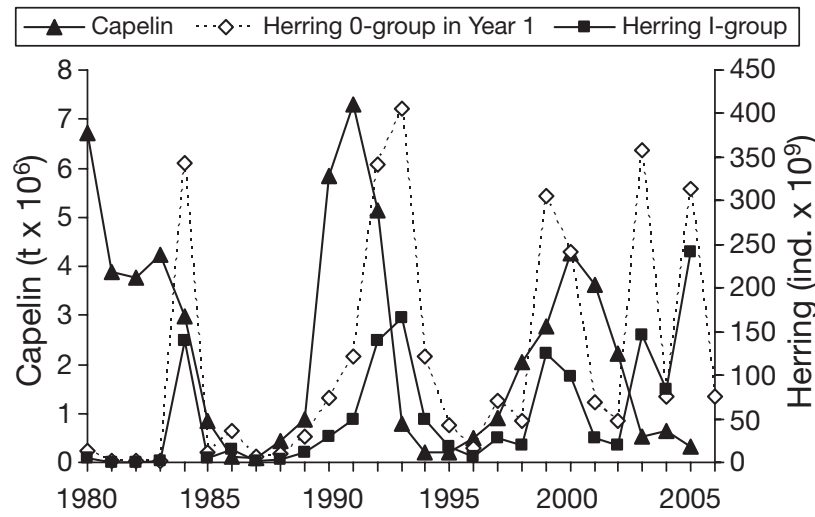

Fig. 1. Mallotus villosus and Clupea harengus. Estimated stock sizes of capelin and herring (2 indices: number of Igroup fish and number of 0 -group fish measured in the previous year) from 1980 to 2005 in the Barents Sea. Data are from ICES $(2006 a, b)$
1982 and 1989, samples collected at Syltefjord $\left(70^{\circ} 35^{\prime} \mathrm{N}, 30^{\circ} 17^{\prime} \mathrm{E}\right)$ in 1985 , a colony $40 \mathrm{~km}$ northwest of Hornøya, were used. Syltefjord is well within the normal foraging range of breeding black-legged kittiwakes $(50$ to $100 \mathrm{~km}$ ) and it is assumed that the birds there fed on the same food base as those on Hornøya.

On return to the laboratory, each sample was thawed, weighed to the nearest $0.1 \mathrm{~g}$ and teased apart under water in a petri dish. All items were identified to the lowest possible taxon using a binocular microscope and the mass of each taxon in each regurgitation was recorded. Whole or partly digested fish were identified from gross morphological characteristics. More digested fish were identified from sagittal otoliths and/or the presence of scales or pro-otic bullae (especially characteristic for herring). Otoliths were often extracted from the undigested skulls of fish or found floating free in the sample. In the last $2 \mathrm{yr}$ of the study (2005 and 2006), the samples were first treated as above and then further digested in a saturated solution of biological washing powder (Biotex) in an oven at $50^{\circ} \mathrm{C}$ for at least $24 \mathrm{~h}$ after which any additional otoliths were collected. Otolith lengths were measured using a calibrated eye-piece graticule in a binocular microscope and were used to determine fish length using published equations for fish from the southern Barents Sea (Table 1). Because the regurgitations were not fully digested, there were no signs of wear to the otoliths, thus eliminating an important source of error when calculating fish lengths (Jobling \& Breiby 1986).

The mean overall diet composition (\% mass) for a given season was calculated using Swanson et al's (1974) aggregated percentage method within 5 d periods, with each period being weighted equally. Results are presented only if at least three $5 \mathrm{~d}$ periods during the main chick rearing period (i.e. after the first chicks were seen in the colony) were sampled. The percent frequency of occurrence of each taxon in the samples was also calculated.

Fledging success. Being one of the most food sensitive indicators of black-legged kittiwakes (Gill et al. 2002), percent fledging success (defined as brood size/clutch size $\times 100$ ) was estimated from counts of eggs in nests (clutch size) made on the day (or very soon after) the first chicks were seen. Later in the season, counts of large (i.e. $20 \mathrm{~d}$ or older) chicks (brood size) from a large sample of nests on the day or soon after the first of the year's chicks was seen flying. Choosing fledging success as opposed to overall breeding success (i.e. the number of chicks fledged per nest occupied at the beginning of the season) reduces the response time window to the chick rearing period and, although in this study not definitive, enables yearto-year comparisons to be made. 
Table 1. Mallotus villosus, Clupea harengus and gadids. Linear relationships between otolith length (OL) and fish length (FL) (both in $\mathrm{mm}$ ) from fish caught in the southern Barents Sea

\begin{tabular}{|lccc|}
\hline Species & Size range $(\mathrm{mm})$ & Equation & Source \\
\hline Capelin Mallotus villosus & $60-140$ & $\mathrm{FL}=48 \mathrm{OL}+25.8$ & Barrett \& Furness (1990) \\
Herring Clupea harengus & $50-280$ & $\mathrm{FL}=58.46 \mathrm{OL}-8.5$ & Jobling \& Breiby (1986) \\
Gadids $^{\mathrm{a}}$ & $50-300$ & $\mathrm{FL}=22.9 \mathrm{OL}-1.68$ & Barrett et al. (1990) \\
aAtlantic cod Gadus morhua and saithe Pollachius virens combined
\end{tabular}

Food abundance. In the absence of independent data on the abundance of the main prey fish within the normal foraging range of black-legged kittiwakes at Hornøya, fish stock data covering the entire Barents Sea were taken from ICES working group reports. Although not an accurate measure, these data are the only ones available and serve as a relative index of food availability for breeding black-legged kittiwakes. The capelin stock assessment is based on joint Russian-Norwegian autumn surveys covering as much of the total stock as possible and is given in tonnes $\times 10^{6}$ (ICES 2006b). Assessments of the youngest age groups of herring that move into the southern Barents Sea to mature were made using the ICES SeaStar VPA (Virtual Population Analysis) model (ICES 2006a). Because black-legged kittiwakes on Hornøya took mainly Igroup (in their 2nd calendar year) herring (see
'Results'), 2 complementary indices of herring abundance were used in this study: that of I-group herring in the concurrent year and that of 0-group herring (in their 1st calendar year) measured in the preceding year (Year 1). The results of ICES' herring assessments are given in number of individuals $\times 10^{9}$.

All statistical tests were run using Minitab ${ }^{\circledR}$ (version 14 for Windows 2003). Percentage values (e.g. fledging success, food composition) were arcsine transformed before regression tests were run.

\section{RESULTS}

Diet. In 21 of the 22 seasons for which data are available for masses of prey landings, capelin and/or herring comprised $\leq 70 \%$ of the diet by mass (Table 2 ,

Table 2. Rissa tridactyla. Composition of black-legged kittiwake adult and chick regurgitations in 1980, 1981, 1983 and 1989 to 2006 at Hornøya and 1985 at Syltefjord, northern Norway. $\mathrm{N}=$ sample size, Other = various identified taxa, Unid. = unidentified taxa, nd = no data

\begin{tabular}{|c|c|c|c|c|c|c|c|c|c|c|c|c|c|c|c|}
\hline \multirow{2}{*}{ Year } & \multirow{2}{*}{$\begin{array}{c}\text { Sample } \\
\text { period } \\
(\mathrm{d} / \mathrm{mo})\end{array}$} & \multirow[b]{2}{*}{$\mathrm{N}$} & \multirow[b]{2}{*}{ Herring } & \multirow{2}{*}{ Capelin } & \multirow{2}{*}{$\begin{array}{c}\text { mass (a } \\
\text { Sand } \\
\text { eel }\end{array}$} & \multirow{2}{*}{$\begin{array}{c}\text { ggregat } \\
\text { Gadid }\end{array}$} & \multirow{2}{*}{ Other } & \multirow[b]{2}{*}{ Unid. } & \multirow[b]{2}{*}{$\begin{array}{c}\text { Total } \\
\text { mass }(\mathrm{g})\end{array}$} & \multirow[b]{2}{*}{ Herring } & \multirow{2}{*}{$\begin{array}{c}\text { - } \% \text { frequ } \\
\text { Capelin }\end{array}$} & \multirow{2}{*}{$\begin{array}{l}\text { ency o } \\
\text { Sand } \\
\text { eel }\end{array}$} & \multirow{2}{*}{$\begin{array}{c}\text { occurre } \\
\text { Gadid }\end{array}$} & \multirow[b]{2}{*}{ Other } & \multirow[b]{2}{*}{ Unid } \\
\hline & & & & & & & & & & & & & & & \\
\hline 1980 & $12 / 6-8 / 7$ & 30 & 0 & 79.5 & 0 & 0 & $20.5^{\mathrm{a}}$ & 0 & 670.7 & 0 & 96.7 & 0 & 0 & 23.3 & 0 \\
\hline 1981 & $30 / 6-31 / 7$ & 30 & 0 & 42.2 & 10.1 & 0 & $45.9^{\mathrm{a}}$ & 1.8 & 524.1 & 0 & 63.3 & 20.0 & 0 & 60.0 & 6.7 \\
\hline 1983 & $29 / 6-19 / 7$ & 72 & nd & nd & nd & nd & nd & nd & nd & 0 & 93.0 & 3.0 & 0 & 4.0 & 0 \\
\hline 1985 & $25 / 6-21 / 7$ & 24 & 47.2 & 41.0 & 6.2 & 0 & 0 & 5.6 & 688.5 & 29.2 & 58.3 & 8.3 & 0 & 0 & 8.3 \\
\hline 1989 & $18 / 6-12 / 7$ & 30 & 0 & 77.3 & 0 & 0 & $22.7^{\mathrm{a}}$ & 0 & 735.6 & 0 & 86.7 & 0 & 0 & 26.7 & 0 \\
\hline 1990 & $26 / 6-25 / 7$ & 63 & 34.7 & 54.2 & 3.8 & 0 & 5.5 & 1.9 & 1176.5 & 41.3 & 50.8 & 7.9 & 0 & 9.5 & 1.6 \\
\hline 1991 & $1 / 6-17 / 7$ & 34 & 38.3 & 61.7 & 0 & 0 & 0 & 0 & 813.0 & 20.6 & 82.4 & 0 & 0 & 0 & 0 \\
\hline 1992 & $21 / 5-16 / 7$ & 90 & 25.3 & 67.6 & 5.6 & 0 & 0.7 & 0.8 & 1471.5 & 37.8 & 66.7 & 4.4 & 0 & 1.1 & 2.2 \\
\hline 1993 & $3 / 7-28 / 7$ & 80 & 90.2 & 6.8 & 0 & 0 & 1.6 & 1.3 & 736.5 & 90.0 & 10.0 & 0 & 0 & 1.3 & 1.3 \\
\hline 1994 & $8 / 7-3 / 8$ & 81 & 89.3 & 1.1 & 0.1 & 7.1 & 0 & 2.4 & 1195.8 & 87.7 & 2.5 & 1.2 & 16.0 & 0 & 3.7 \\
\hline 1995 & $25 / 6-27 / 7$ & $\begin{array}{r}01 \\
103\end{array}$ & 75.9 & $\begin{array}{r}1.1 \\
14.3\end{array}$ & 0.4 & 0.1 & $9.2^{\mathrm{a}}$ & $\begin{array}{c}2.4 \\
0\end{array}$ & 1704.0 & 78.6 & 21.4 & $\begin{array}{l}1.2 \\
1.9\end{array}$ & $\begin{array}{l}10.0 \\
1.0\end{array}$ & 9.7 & $\begin{array}{c}0.1 \\
0\end{array}$ \\
\hline 1996 & $1 / 7-30 / 7$ & 53 & 7.8 & 63.6 & 0.1 & 1.6 & $7.1^{\mathrm{a}}$ & 20 & 1282.5 & 11.3 & 73.6 & 1.9 & 7.5 & 26.4 & 7.5 \\
\hline 1997 & $16 / 6-17 / 7$ & 65 & 2.6 & 84.7 & 2.5 & 8 & 2.1 & 0 & 1013.0 & 6.2 & 90.8 & 6.2 & 6.2 & 6.2 & 0 \\
\hline 1998 & $1 / 6-9 / 7$ & 84 & 2.8 & 81.5 & 0 & 0.3 & $12.2^{\mathrm{a}}$ & 3.1 & 1546.0 & 2.4 & 89.3 & 0 & 1.2 & 20.2 & 2.4 \\
\hline 1999 & $6 / 6-14 / 7$ & 81 & 30.6 & 65.8 & 0.4 & 3.2 & 0 & 0 & 1286.0 & 28.4 & 76.5 & 1.2 & 6.2 & 1.2 & 0 \\
\hline 2000 & $5 / 6-20 / 7$ & 76 & 36.4 & 40.9 & 3.7 & 15 & 3 & 1.3 & 1157.0 & 46.1 & 53.9 & 3.9 & 5.3 & 6.6 & 1.3 \\
\hline 2001 & $9 / 6-9 / 7$ & 36 & 24.5 & 75.5 & 0 & 0 & 0 & 0 & 647.0 & 19.4 & 86.1 & 0 & 0 & 0 & 0 \\
\hline 2002 & $2 / 6-29 / 6$ & 66 & 0.6 & 93.5 & 0 & 0 & $5.9^{\mathrm{b}}$ & 0 & 929.0 & $\begin{array}{c}17.4 \\
1.5\end{array}$ & 84.8 & 0 & 0 & 15.2 & 0 \\
\hline 2003 & $6 / 7-15 / 7$ & 16 & 66.9 & 21.2 & 0 & 5.0 & $6.3^{\mathrm{b}}$ & 0.7 & 119.0 & 68.8 & $\begin{array}{l}04.0 \\
25.0\end{array}$ & 0 & 12.5 & $\begin{array}{l}10.2 \\
6.3\end{array}$ & 6.3 \\
\hline 2004 & $22 / 6-12.7$ & 44 & 50.8 & 37.8 & 1.4 & 9.0 & 0.3 & 0.7 & 935.0 & 65.9 & 22.7 & 4.5 & 18.2 & 2.3 & 2.3 \\
\hline 2005 & $24 / 6-19 / 7$ & 79 & 67.7 & 29.2 & 0.7 & 0.5 & 0.6 & 1.3 & 793.7 & 75.9 & 20.3 & 2.5 & 1.3 & 1.3 & 1.3 \\
\hline 2006 & $23 / 6-21 / 7$ & 48 & 89.8 & 0 & 0 & 9.6 & 0.6 & 0 & 472.1 & 87.5 & 0 & 0 & 15 & 4.2 & 0 \\
\hline
\end{tabular}


Fig. 2). The only exception was 1981 when euphausiids made up $46 \%$ of the total diet by mass. Capelin was the most common food item and comprised $\leq 50 \%$ of the diet by mass in 11 seasons, whereas herring dominated in 7 seasons (1993 to 1995 and 2003 to 2006). In terms of frequency of occurrence, capelin was again very common, with the species occurring in $>50 \%$ of the samples in 15 seasons, while herring was equally common in 6 seasons only (1993 to 1995 and 2003 to 2006; Table 2).

Size of fish. The lengths of 74 herring, 460 capelin and 179 gadids were calculated from measurements of otoliths. Most of the herring taken were 90 to $160 \mathrm{~mm}$ long (Fig. 2). Although the distribution pattern suggests 3 year classes of herring, the 2 peaks at 90 to 100 and $140 \mathrm{~mm}$ fall within the length ranges of 0 - and Igroup herring caught in the Barents Sea in autumn (Johansen 2003). The capelin were mainly 110 to $160 \mathrm{~mm}$ long and, thus, 2 or more years old (Gjøsæter 1998). The gadids were either Atlantic cod Gadus morhua or saithe Pollachius virens and their main length distribution was 30 to $60 \mathrm{~mm}$, i.e. 0-group fish (Barrett et al. 1990).

Diet versus fish abundance. Plots of diet composition expressed both as percent mass and as percent frequency of occurrence against the independent estimates of fish abundance showed clear positive relationships (Fig. 3). Using logarithmic regressions, the ICES estimates of the total stocks of capelin and both indices of I-group herring explained 20 to $40 \%$ of the variability in the amount of capelin and herring, respectively, in the chick diet in a given year.

Regurgitation mass. The overall mean mass of adult regurgitations was $22.4 \mathrm{~g}(\mathrm{SE}=0.6, \mathrm{n}=545)$ and of chick regurgitations was $11.0 \mathrm{~g}(\mathrm{SE}=0.4, \mathrm{n}=492)$. Although the mean masses of regurgitations from adults and chicks varied greatly from year to year, both dropped by $30 \%$ (from 27.5 to $19 \mathrm{~g}$ ) and ca. $55 \%$ (from 17.5 to $7.5 \mathrm{~g}$ ), respectively, between 1980 and 2006

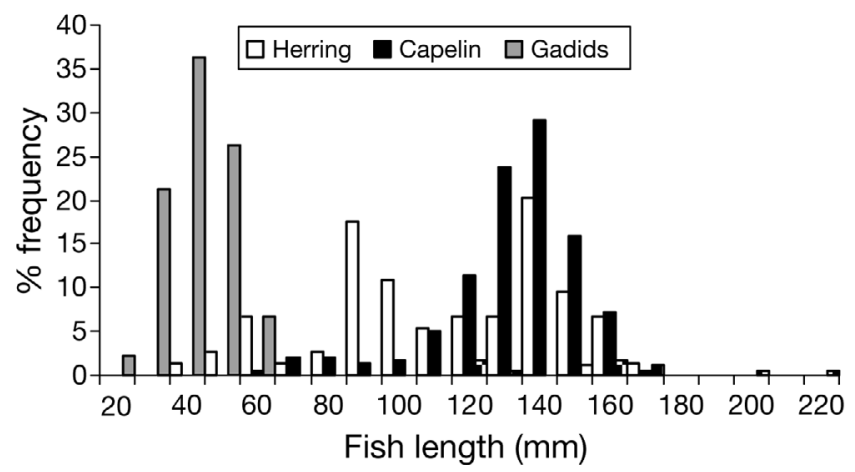

Fig. 2. Clupea harengus, Mallotus villosus and gadids. Length frequency distribution of 74 herring, 460 capelin and 179 gadids fed to black-legged kittiwake chicks at Hornøya, 1980 to 2006

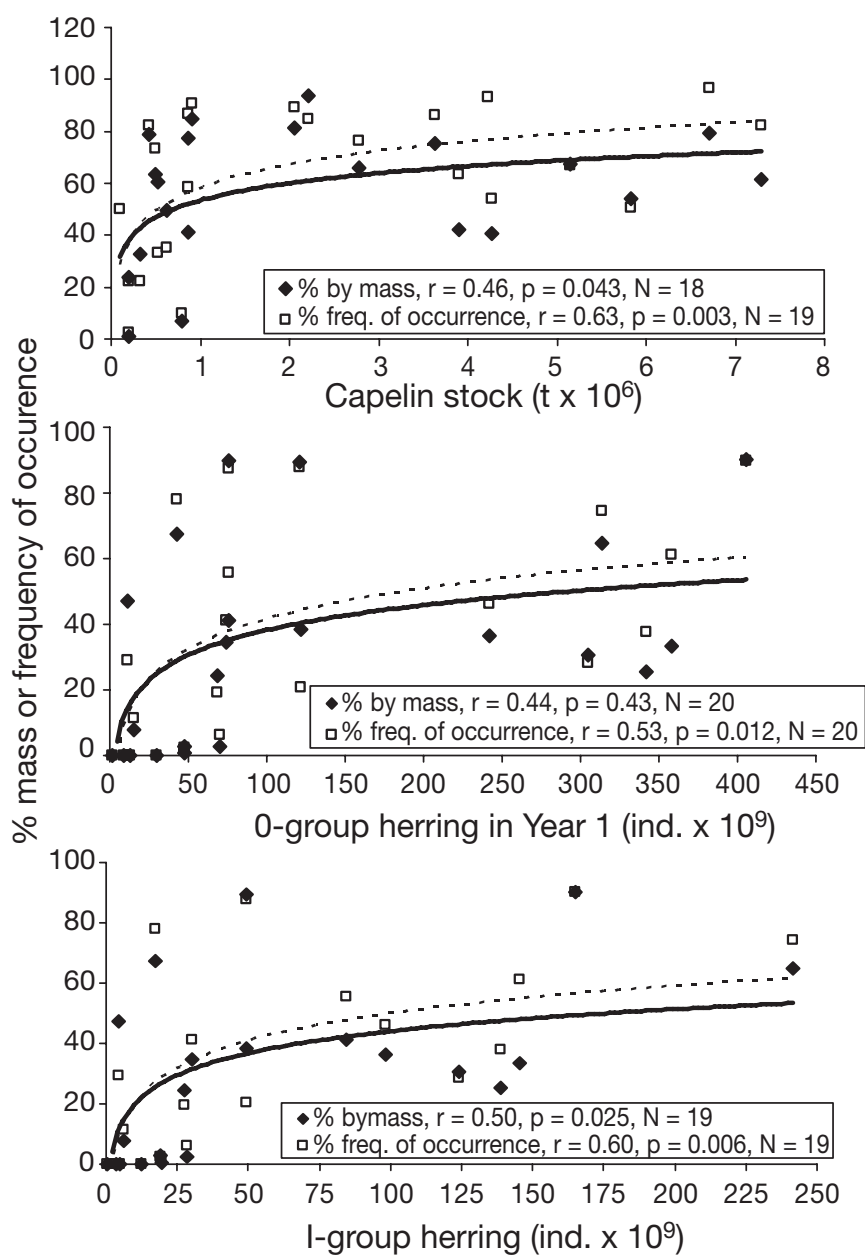

Fig. 3. Rissa tridactyla, Mallotus villosus and Clupea harengus. Relationship between black-legged kittiwake chick diet composition (\% by mass and \% frequency of occurrence) and independent estimates of the abundance of capelin (total stock), 0-group herring (in Year 1) and I-group herring. Logarithmic regression curves are fitted to the data sets (solid line $=\%$ by mass, dotted line $=\%$ frequency of occurrence)

(Fig. 4). Adult regurgitations dominated by capelin or herring ( $>50 \%$ by mass) weighed $23.1 \mathrm{~g}(\mathrm{SE}=0.7, \mathrm{n}=$ $360)$ and $20.3 \mathrm{~g}(\mathrm{SE}=0.9, \mathrm{n}=161)$, respectively (Student's $t$-test: $t=2.4, \mathrm{p}=0.015$ ), while the equivalent chick regurgitations weighed $13.1 \mathrm{~g}(\mathrm{SE}=0.6, \mathrm{n}=163)$ and $9.7 \mathrm{~g}(\mathrm{SE}=0.4, \mathrm{n}=302)$, respectively (Student's $t$ test: $t=4.7, \mathrm{p}<0.001$ ). Regressions also showed how the size of the regurgitations decreased with both the amount of herring in the diet and the amount of herring in the sea with 6 of 8 possible correlations being significant (Table 3). There was an opposite but weaker tendency in relation to capelin (Table 3).

Fledging success. Although there was no long-term change in clutch size between 1980 and $2006(\mathrm{r}=0.01$, $\mathrm{p}=1.0, \mathrm{n}=23$ ), fledging success declined significantly between 1980 and 2006 (Fig. 5). Although exploratory 


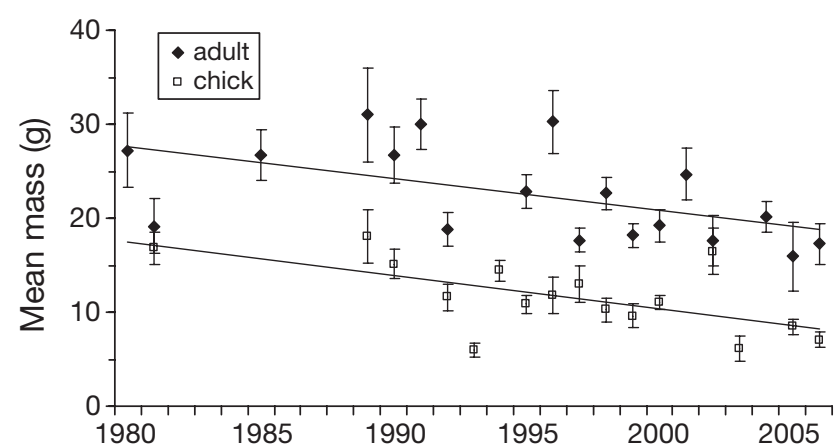

Fig. 4. Rissa tridactyla. Mean mass $( \pm \mathrm{SE})$ of regurgitations from black-legged kittiwake adults and chicks during the main chick rearing period at Hornøya (1980, 1981 and 1989 to 2006) and Syltefjord (1985). (Equations for trend lines: adult = $740.0-0.360 y, r=0.59, \mathrm{p}=0.017$; chick $=719.1-0.354 y$, $\mathrm{r}=0.61, \mathrm{p}=0.012$ )

analyses of fledging success in relation to either diet choice or fish abundance (capelin, 0-group in Year 1 and I-group herring) showed no significant relationships, there were tendencies towards positive relationships with respect to capelin and negative ones with respect to herring (Table 3). Although the trends were positive, there was no significant relationship between fledging success and either chick or adult regurgitation mass $(r=0.33$ and 0.28 , respectively, $\mathrm{p}>0.2)$.

\section{DISCUSSION}

Black-legged kittiwakes are among the seabirds most vulnerable to changes in food availability because they are relatively small surface-feeders, have little 'spare' time in their activity budget and have a diet composed of relatively few species (Furness \& Tasker 2000). As a result, their breeding success is variable and liable to

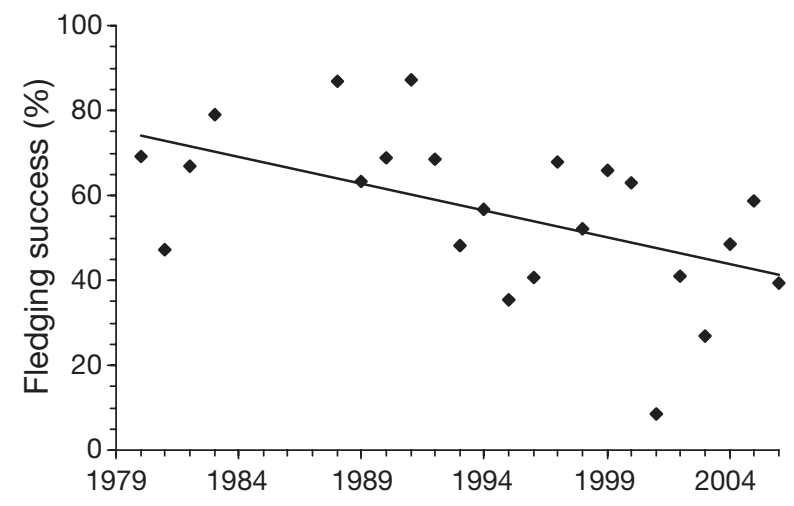

Fig. 5. Rissa tridactyla. Fledging success (\% large chicks/eggs laid) of black-legged kittiwake chicks at Hornøya between 1980 and 2006. (Equation for trend line: fledging success $=$ $31.97-0.016 y, r=0.53, p=0.010$ )

respond to the availability of prey within the normal foraging range ( 50 to $100 \mathrm{~km}$ ) from the breeding colony. Black-legged kittiwakes are typically piscivorous and, in western Europe, feed on energy-rich fish such as sand eels Ammodytes spp., capelin, herring and sprat Sprattus sprattus, but they may also scavenge for discards and offal thrown from fishing boats (Heubeck 2004, this study). In some areas, e.g. the northwestern North Sea where a large part of the UK black-legged kittiwake population breeds, they feed predominately on one species, the lesser sand eel $A$. marinus, only during the chick-rearing period and seem constrained in their ability to switch to other species when sand eel availability is low and alternative prey appears readily available (Lewis et al. 2001). Similarly, black-legged kittiwakes in Newfoundland and Labrador, Canada, appear to be dependent on a single item, the capelin, and their breeding success is often poor at these colonies when capelin abundance is low (Carscadden et al. 2002).

Table 3. Rissa tridactyla. Linear correlations between mass of regurgitations and fledging success of black-legged kittiwake adults and chicks at Hornøya, northern Norway, and diet choice and independent estimates of stocks of capelin, 0-group herring (measured in the previous year) and I-group herring in the Barents Sea. Significant relationships are indicated by $p$ values $<0.05$ in bold

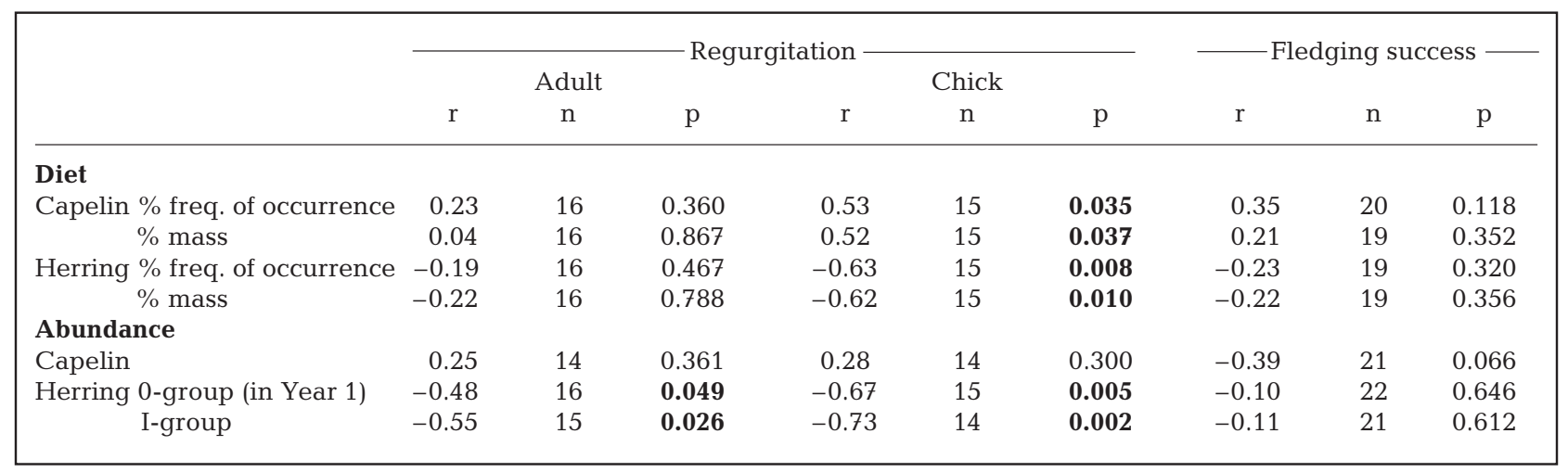


At Hornøya, the diet is predominantly capelin and/or I-group herring and the adults readily switch between the 2 species. The amount taken of either prey is, however, only significant when the prey abundance is high. For example, capelin stocks need to be at a minimum of $1 \times 10^{6} \mathrm{t}$ before capelin dominates the diet (Fig. 3). Similarly, the amount of herring in the diet does not become significant until numbers of I-group herring reach a threshold of 25 to $50 \times 10^{9}$ individuals. Such a threshold relationship has previously been found between the northern gannet Morus bassanus and the commercial harvest of squid off Newfoundland and may be a result of the difference in spatial scales at which the avian predators and fisheries scientists sample the fish stocks (Montevecchi \& Myers 1995). For black-legged kittiwakes, the foraging range of breeding birds is up to ca. $100 \mathrm{~km}$ of a colony, while capelin surveys generally cover much larger areas. In Norway, the latter entails the entire Barents Sea where, in summer, much of the capelin stock feeds in the northern waters beyond the mainland-breeding kittiwakes' foraging range. It is, thus, probable that the threshold effect seen in this study may also be a sampling artefact showing that fish stock data are not necessarily a good index of food availability at a given colony.

The youngest age groups of herring in the Barents Sea have, however, a more coastal distribution than capelin, thus increasing the chances of a larger spatial overlap between foraging kittiwakes and fisheries surveys (Loeng 1989); although there are again considerable annual variations in the herring distribution. For example, in 2003 the large numbers of young herring (Fig. 1) were distributed far southwest of the North Cape, whereas in 2005, another year with many herring, they were spread along the entire coast of Finnmark including the waters off Hornøya (Norwegian Institute of Marine Research unpubl. cruise reports). Access to capelin in 2003 was also very limited due to a springtime spawning migration much farther west than normal, resulting in a 2 to $3 \mathrm{wk}$ abandonment of Hornøya during the early laying period, a late breeding season and very low breeding success (Fig. 5; Barrett et al. 2004).

Both capelin and I-group herring of the sizes taken by kittiwakes ( 80 to $160 \mathrm{~mm}$ ) are rich in lipids, protein and energy (>6 kJ g ${ }^{-1}$ wet mass; Furness \& Barrett 1985, Hislop et al. 1991, R. T. Barrett unpubl.) such that, on the outset, the choice of one or the other would not be expected to have a detrimental effect on breeding success. The results of this study suggest otherwise and that although both species were periodically abundant, a diet of herring resulted in lower regurgitation masses. Lower meal sizes may, of course, be compensated for by higher feeding rates, a variable that strongly affects black-legged kittiwake productivity
(Jodice et al. 2006b). The tendency towards a lower breeding success on Hornøya with diets of herring rather than capelin nevertheless suggests that the former were more difficult to access.

One possible explanation is that differences in schooling behaviour make capelin easier to catch than herring. For example, attacks by predatory fish often bring prey fish to the surface, but young herring form very dense ball-like shoals providing protection, while capelin disperse and, therefore, have a weaker avoidance reaction (T. Pedersen pers. comm.).

It may be argued that herring is easier to digest than capelin, resulting in lighter regurgitations. This is, however, unlikely, not only because both species have a high energy density and, thus, are easily assimilated (Hilton et al. 2000a), but also because in vitro experiments have shown that capelin was much easier to digest than another clupeid, the sprat (Hilton et al. 1998). However, even if herring was easier to digest, Hilton et al. (2000b) presented a model predicting that rapid digestion is favoured when energy costs of foraging are high, while slow digestion is preferable when costs are low. Thus, regurgitations of herring being lighter than those of capelin suggest that either herring was more difficult to access and/or the herring was rapidly digested because energy costs of accessing it were higher than when catching capelin. Either case supports earlier suggestions that capelin is the preferred prey.

One should note, however, that these results do not take into account the years when chicks or adults were reluctant to, or could not, regurgitate food. Although the proportions of birds handled that actually regurgitated is unknown, very few samples were collected from many birds handled in 2001 and 2003 (Table 2). This suggests that, although numbers of I-group herring were high in at least 2003 (Fig. 1), food was difficult to access during those years and resulted in the very low fledging successes (Fig. 5).

Although there were no clear effects of diet choice or abundance of fish on the fledging success, there was an overall decline in the latter after 1980 when herring spawning stocks increased and more juvenile herring appeared in the Barents Sea and capelin stocks were very low $\left(<1 \times 10^{6}\right.$ t) in 13 years (Fig. 1). Furthermore, the tendencies toward a lower success when herring is present and a higher success when capelin is present (Table 3 ) again point to capelin as the preferred prey for black-legged kittiwakes.

The fact that increased herring abundance is probably acting negatively on black-legged kittiwakes at Hornøya is the reverse of the positive effect found at some colonies in Prince William Sound, Alaska, where an increased abundance of juvenile Pacific herring Clupea pallasi resulted in higher delivery rates, chick 
growth and breeding success (Suryan \& Irons 2001, Jodice et al. 2006a). This was, however, at the expense of female parental effort, which increased with juvenile herring abundance, though probably not at a rate high enough to compromise lifetime reproductive success (Jodice et al. 2006a). The positive effect of increases in juvenile herring in Prince William Sound is in contrast to the negative effect found in this study. This may be because the Prince William Sound herring were in a bay and occurred inshore and near the surface (Ainley et al. 2003) and, thus, were easier to find and catch than those in northern Norway, which are in the deeper open ocean. In addition, at Røst in the Lofoten Islands, northern Norway, the black-legged kittiwake breeding success was high above a certain threshold of 0-group herring (Anker-Nilssen et al. 1997). Other colonies in Prince William Sound had periodical access to both sand eels (e.g. Pacific sand lance Ammodytes hexapterus) and capelin and substantial variation in annual rates of productivity were associated with diet composition (Jodice et al. 2006a). When prey were close to the colony, production was high, but when prey was difficult to access breeding failure was common (Jodice et al. 2006b).

In an earlier study at Hornøya, Barrett (2002) found strong, linear correlations between diet choice and capelin and herring abundance for both Atlantic puffins Fratercula arctica and common guillemots Uria aalge. The fact that the best fit for surface-feeding black-legged kittiwakes was curvilinear (logarithmic) and the smaller, shallower-diving Atlantic puffin showed weaker relationships than the larger, deeperdiving common guillemots supports the hypothesis that such relationships will be weaker among species that have a more restricted foraging capacity. This was corroborated by Anker-Nilssen et al. (1997), who found that the food abundance threshold above which breeding was successful was higher for black-legged kittiwakes than for Atlantic puffins.

Fisheries affect seabird communities in numerous ways, both directly and indirectly (Furness 2003). Earlier studies have shown how the post-1970 abundance of capelin in the Barents Sea, which was a result of the partly fisheries-induced collapse of the Norwegian spring-spawning herring stocks in the late 1960s, favoured seabirds in the region and resulted in high breeding success and increasing numbers (Krasnov \& Barrett 1995). It now appears that the present recovery of the herring stocks and the periodically large numbers of young herring in the Barents Sea are having a negative effect, through their predation, on capelin recruitment (Hjermann et al. 2004). In this instance, the effect has permeated up the food chain to negatively affect a top predator, the black-legged kittiwake.
If the present climate warming continues, the capelin stock faces an even more uncertain future in the Barents Sea ecosystem through both a northward shift in distribution into less favourable waters and an increased predation pressure from herring and cod (Hjermann et al. 2004). The consequences of this on the life history of black-legged kittiwakes remain to be seen. The question of a possible long-term cycle in numbers of and breeding success of black-legged kittiwakes as a result of similar cycles found for capelin, herring and cod in the Barents Sea (Yndestad 2003) should also be addressed.

Acknowledgements. I am very grateful to T. Boulinier (CNRS, Montpellier, France) and his co-workers for help in collecting the food samples, T. Pedersen (Norwegian College of Fishery Science, University of Tromsø) for information concerning fish swimming behaviour, H. Gjøsæther (Norwegian Institute of Marine Research, Bergen) for access to unpublished cruise reports, and to T. Anker-Nilssen (Norwegian Institute for Nature Research), W. A. Montevecchi (Memorial University, St. John's, Newfoundland and Labrador) and 3 referees for their comments on an earlier draft of the manuscript. The study was financed by Tromsø University Museum, the Norwegian National Monitoring Programme for Seabirds and the Norwegian SEAPOP project (http://seapop.no/).

\section{LITERATURE CITED}

Ainley DG, Ford RG, Brown ED, Suryan RM, Irons DB (2003) Prey resources, competition, and geographic structure of kittiwake colonies in Prince William Sound. Ecology 84:709-723

Anker-Nilssen T, Barrett RT, Krasnov JV (1997) Long- and short-term responses of seabirds in the Norwegian and Barents Seas to changes in stocks of prey fish. In: Forage fishes in marine ecosytems. Univ Alaska Sea Grant College Program, Fairbanks, p 683-698

Barrett RT (2002) Atlantic puffin Fratercula arctica and common guillemot Uria aalge chick diet and growth as indicators of fish in the Barents Sea. Mar Ecol Prog Ser 230:275-287

Barrett RT, Furness RW (1990) The prey and diving depths of seabirds on Hornøy, North Norway after a decrease in the Barents Sea capelin stocks. Ornis Scand 21:179-186

Barrett RT, Krasnov YV (1996) Recent responses to changes in stocks of prey species by seabirds breeding in the southern Barents Sea. ICES J Mar Sci 53:713-722

Barrett RT, Røv N, Loen J, Montevecchi WA (1990) Diets of shags Phalacrocorax aristotelis and cormorants $P$. carbo in Norway and possible implications for gadoid stock recruitment. Mar Ecol Prog Ser 66:205-218

Barrett RT, Josefsen TD, Polder A (2004) Early spring wreck of Black-legged Kittiwakes Rissa tridactyla in North Norway, April 2003. Atl Seabirds 6:33-45

Barrett RT, Lorentsen SH, Anker-Nilssen T (in press) The status of breeding seabirds in mainland Norway. Atl Seabirds

Carscadden JE, Montevecchi WA, Davoren GK, Nakashima BS (2002) Trophic relationships between capelin (Mallotus villosus) and seabirds in a changing ecosystem. ICES J Mar Sci 59:1027-103

Furness RW (2003) The impact of fisheries on seabird communities. Sci Mar 67:33-45 
Furness RW, Barrett RT (1985) The food requirements and ecological relationships of a seabird community in North Norway. Ornis Scand 16:305-313

Furness RW, Tasker ML (2000) Seabird-fishery interactions: quantifying the sensitivity of seabirds to reductions in sandeel abundance, and identification of key areas for sensitive seabirds in the North Sea. Mar Ecol Prog Ser 202: 253-264

Gill VA, Hatch SA, Lanctot RB (2002) Sensitivity of breeding parameters to food supply in Black-legged Kittiwakes Rissa tridactyla. Ibis 144:268-283

Gjøsæter H (1998) The population biology and exploitation of capelin (Mallotus villosus) in the Barents Sea. Sarsia 83: 453-496

Heubeck M (2004) Black-legged kittiwake Rissa tridactyla. In: Mitchell PI, Newton SF, Ratcliffe N, Dunn TE (eds) Seabird populations of Britain and Ireland. Results of the Seabird 2000 census (1998-2000). T. \& A. D. Poyser, London, p 277-290

Hilton GM, Houston DC, Furness RW (1998) Which components of diet quality affect retention time of digesta in seabirds? Funct Ecol 12:929-939

Hilton GM, Furness RW, Houston DC (2000a) The effects of diet switching and mixing on digestion in seabirds. Funct Ecol 14:145-154

Hilton GM, Ruxton GD, Furness RW, Houston DC (2000b) Optimal digestion strategies in seabirds: a modelling approach. Evol Ecol Res 2:207-230

Hislop JRG, Harris MP, Smith JGM (1991) Variation in the calorific value and total energy content of the lesser sandeel (Ammodytes marinus) and other fish preyed on by seabirds. J Zool 224:501-517

Hjermann DØ, Stenseth NC, Ottersen G (2004) Indirect climate forcing of the Barents Sea capelin: a cohort effect. Mar Ecol Prog Ser 273:229-238

ICES (2006a) Report of the Arctic fisheries working group (AFWG). ICES CM 2006/ACFM:25

ICES (2006b) Report of the northern nelagic and blue whiting fisheries working group (WGNPBW). ICES CM 2006/ ACFM:34

Iversen SA, Fossum P, Gjøsæter H, Skogen M, Toresen R (eds) (2006) Havets ressurser og miljø 2006. Fisken og Havet Særnr 1-2006. Havforskningsinstituttet, Bergen

Editorial responsibility: Rory Wilson,

Swansea, UK
Jobling M, Breiby A (1986) The use and abuse of fish otoliths in studies on feeding habits of marine piscivores. Sarsia 71:265-274

Jodice PGR, Roby DD, Suryan RM, Irons DB, Turco KR, Brown ED, Thedinga JF, Visser GH (2006a) Increased energy expenditure by a seabird in response to higher food abundance. Mar Ecol Prog Ser 306:283-293

Jodice PGR, Roby DD, Turco KR, Suryan RM and 6 others (2006b) Assessing the nutritional stress hypothesis: relative influence of diet quantity and quality on seabird productivity. Mar Ecol Prog Ser 325:267-279

Johansen GO (2003) Size-dependent predation on juvenile herring (Clupea harengus) by Northeast Arctic cod (Gadus morhua) in the Barents Sea. Sarsia 88:136-153

Krasnov JV, Barrett RT (1995) Large-scale interactions among seabirds, their prey and humans in the southern Barents Sea. In: Skjoldal HR, Hopkins C, Erikstad KE, Leinaas HP (eds) Ecology of fjords and coastal waters. Elsevier Science BV, Amsterdam, p 443-456

Krasnov YV, Barrett RT, Nikolaeva NG (2007) Status of Blacklegged Kittiwakes Rissa tridactyla, Common Guillemots Uria aalge and Brünnich's Guillemots $U$. lomvia in Murman, NW Russia and in Varanger, NE Norway. Polar Res 26:113-117

Lewis S, Wanless S, Wright PJ, Harris MP, Bull J, Elston DA (2001) Diet and breeding performance of black-legged kittiwakes Rissa tridactyla at a North Sea colony. Mar Ecol Prog Ser 221:277-284

Loeng H (1989) Ecological features of the Barents Sea. In: Rey L, Alexander V (eds) Proc 16th Conf Comité Arctique Int. Brill Academic Publishers, Leiden, p 443-456

Montevecchi WA, Myers RA (1995) Prey harvests of seabirds reflect pelagic fish and squid abundance on multiple spatial and temporal scales. Mar Ecol Prog Ser 117:1-9

Suryan RM, Irons DB (2001) Colony and population dynamics of Black-legged Kittiwakes in a heterogeneous environment. Auk 118:636-649

Swanson GA, Krapu GL, Bartonek JC, Serie JR, Johnson DH (1974) Advantages in mathematically weighting waterfowl food habits data. J Wildl Manag 38:302-307

Yndestad H (2003) The code of the long-term biomass cycles in the Barents Sea. ICES J Mar Sci 60:1251-1264

Submitted: April 3, 2007; Accepted: June 20, 2007

Proofs received from author(s): October 29, 2007 